\title{
THE IMPACT OF SOIL AND CLIMATIC FACTORS ON FOREST GROWTH
}

\author{
KITTI BALOG ${ }^{1}$, ANDRÁS SZABó $^{2}$, JÁNOS RÁSÓ $^{2}$ \\ ${ }^{1}$ Institute for Soil Science and Agricultural Chemistry, CAR HAS \\ Budapest, Hungary, 1525 Budapest, Pf. 102. \\ balog.kitti@agrar.mta.hu \\ ${ }^{2}$ Forest Research Institute, NARIC, \\ Budapest, Hungary, 1023 Frankel Leó str. 42. \\ szaboa@erti.hu,rasoj@erti.hu
}

\begin{abstract}
This preliminary study reveals the relations between the forest growth (annual dendromass increment; $\mathrm{ADM}_{\mathrm{inc}}$ - as dependent variable) and some important soil factors, which have effect on plant growth, such as: groundwater level (GWL), groundwater composition (GWC), plant available water capacity (PAWC), depth of humus layer, texture (hy $)$ and $\mathrm{pH}$ of the soil, moreover the maximum concentration (MAX) of salt and $\mathrm{CaCO}_{3}$ and the depth of its MAX in the soil profile. 17 plantations (Poplar, Common oak and Black locust) are included in the analysis investigated all over the Great Hungarian Plain. Correlation profile of the above parameters was created explaining that two abiotic parameters limit plant growth: if GWL is deeper than $5 \mathrm{~m}$ and if $\mathrm{HCO}_{3}$ concentration in groundwater is high (above $15 \mathrm{meq} / \mathrm{L}$ ). Within the tested range $(0.17-2.23$ $\mathrm{mS} / \mathrm{cm}$ for electrical conductivity (EC) and $0.5 / \mathrm{sand} /-4.21 /$ clay loam/ for hy 1 ), the higher magnitude of EC

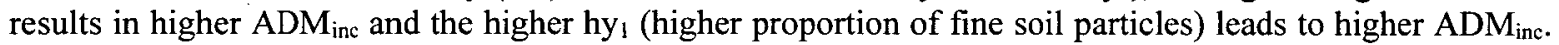
The positive relationship of $\mathrm{ADM}_{\text {inc }}$ with EC suggests good nutrient supply of the soil, while the higher proportion of fine particles refers to better water management properties. Thickness of humus layer is an important soil factor: compared to shallow humus layer, deep one increases $\mathrm{ADM}_{\text {inc }}$ exponentially. In case of Black locust, PAWC is the substantial factor for growing, unlike Poplar, whose growth depends on groundwater uptake (GWU). This phenomenon originates from the differences between the individual needs of the tree species and differences in root morphology.

Merely 4 sampling plots were equipped with meteorological stations, thus the number of climatic parameter data were not enough for statistical analysis. So data for all 17 plots were collected from literature and a general, regionally calculated data were applied (mean rainfall in the vegetation period and aridity index). There was no significant correlation between climatic parameters and $A D M_{\text {inc }}$.

Further studies and more field investigations are needed in order to clarify the results.
\end{abstract}

Keywords: dendromass production, groundwater level and composition, soil factors

\section{INTRODUCTION}

The aim of this preliminary study is to reveal the factors influencing tree growth (dendromass production) in planted Poplar (Populus $\times$ canadensis), Common oak (Quercus robur) and Black locust (Robinia pseudoacacia) forests of Hungary. 70 plantations were investigated all over the Great Hungarian Plain. Out of them, 17 forests were re-examined a few years later to get information about the growth of the plantation. Soil and groundwater chemical and physical data, moreover biotic and climatic data are included in our database, used for statistical analysis.

According to our hypothesis, dendromass production is influenced by the parameters below:

- groundwater level (GWL) (compared to the depth of active water uptake zone of the roots) (TÜFEKCIOGLU ET AL., 2005; VAN SLYCKEN AND VEREECKEN, 1990),

- groundwater chemical composition (GWC),

- plant available water capacity (PAWC) of the soil (BERGANTE ET AL., 2010), 
- depth of humus layer in the given soil (type),

- $\quad \mathrm{pH}$ of the soil (availability of the elements) (DI BENE ET AL., 2011; GUO AND HAN, 2008; TÜFEKCIOGLU ET AL., 2005),

- maximum concentration (MAX) of sait and $\mathrm{CaCO}_{3}$, and the depth of $\mathrm{MAX}$ in the soil profile (compared to the depth of root zone) (CARTER, 1981; EVERS ET AL, 1997),

- texture of the soil in the root zone (hy1) (DECKMYN ET AL., 2004; TÜFEKCIOGLU ET AL., 2005),

- mean rainfall in the vegetation period (BERGANTE ET AL., 2010, MichELOT ET AL., 2012),

- $\quad$ aridity index (drought) (DECKMYN ET AL., 2004, DöVÉNYI, 2010, KUSTER ET AL., 2013, ZANG ET AL., 2012).

\section{MATERIAL AND METHOD}

The sampling sites were selected based on the categories of geologic maps of surface sediments and soils (KUTI ET AL. 1981, 1982, 1984, 1986), considering water table level, salinity and soil texture. In addition, databases of tree plantations describing forest tree species (Poplar, Common oak, Black locust) and stand age were used (TóTH ET AL. 2001). The 70 investigated forests were surveyed between 2012 July and 2014 August, and 17 of them was re-examined in 2015 September. Out of these 17 forests, 11 were supplied with groundwater monitoring equipment. The groundwater pressure sensors were measuring water table level in every 15 minutes and have stored measured data. 4 meteorological stations were set up in the control stands (nearby croplands and grasslands), which also recorded air temperature, relative humidity, solar radiation and the amount of rainfall every 15 minutes.

To avoid edge effect, boreholes for soil sampling were located at least $50 \mathrm{~m}$ away from the border of the plantation. The maximum depth of the boreholes was $11 \mathrm{~m}$ as limited by the augering equipment. Soil sampling was done to the depth of groundwater table +1 meter. The samples were taken at every $20 \mathrm{~cm}$ increment from the topsoil to $1 \mathrm{~m}$ and at every 50 $\mathrm{cm}$ increment below $1 \mathrm{~m}$.

Water samples were taken in every case, when water table level was $<10 \mathrm{~m}$ with hand vacuum pump. Samples were stored at cool conditions until laboratory analysis. Field pH and electrical conductivity (EC) measurement was performed on every water sample.

In forest stands, biomass assessment, consisting of tree height measurement and stem circumference at the height of $130 \mathrm{~cm}$ was carried out. Dendromass $\left(\mathrm{m}^{3} / \mathrm{ha}\right)$ was calculated from the above data for all the three tree species.

Active water uptake zone of the roots was identified based on the location of the maximums of $\mathrm{Cl}^{-}$and EC in the soil. Namely, during water uptake from groundwater, salts and chloride (as an inert element) are excluded by the roots and accumulated in a defined soil layer, which is parallel with water uptake zone. If there were huge differences between the depth of the two maximums, $\mathrm{Cl}$ maximum was the decisive, because $\mathrm{EC}$ maximum could be determined by a large number of other variables beside salt content.

Groundwater uptake (GWU) was calculated based on the method of NOSETTO ET AL. (2007). Calculation was performed on the basis of the difference of total soil chloride content of the plantation and control grassland down to the bottom of root zone, and the groundwater chloride concentration below the root zone, considering the age of plantation. Statistical analysis was carried out with SPSS 11.5. Spearman's rank correlation was applied due to the distribution of the data. Linear regression (LR), linear discriminant 
analysis (LDA) and analysis of variance (ANOVA) was carried out for modeling the relationship between the variables and for explaining the influencing factors on the dependent variable, the tree growth.

\section{RESULTS}

Results of statistical analysis performed based on our hypothesis are presented hereinafter. There was no significant correlation between tree growth (annual dendromass increment: ADMinc; $\left[\mathrm{m}^{3} /\right.$ ha/year]) and the groundwater level (GWL; [m]) compared to the depth of active water uptake zone of the roots. Although it was stated, that GWL (above $5 \mathrm{~m}$ depth) have significant $(\mathrm{p}=0.074)$ and strong negative $\left(\mathrm{r}_{\mathrm{Sp}}=-0.71\right)$ correlation with $\mathrm{ADM}$ inc $(\mathrm{N}=7)$. This means that shallower water table causes greater increase in ADMinc, and $5 \mathrm{~m}$ is the limit for forests on the Great Plain to get water from groundwater for optimal growth. Two main field parameters were applied to calculate $\mathrm{ADM}_{\text {inc }}$ for each tree type: tree height and diameter. According to the relevant literature (for poplar), there is a definite correlation between the height growth and the relative position of the water table in the soil (TüfeKcIOGLU, 2005; PruitT, 1947). Positive correlation - can be revealed between these parameters - is valid only down to a certain optimum depth (a few decimeters, according to tree types) (PRUITT, 1947). Beneath this optimum depth, growth of trees is inversely correlated with groundwater depth ( 7 to $23 \mathrm{~m} ; \mathrm{R}^{2}=0.69, \mathrm{P}=0.025$; GRIES ET AL, 2003). According to additional results of MAHONEY AND ROOD (1992), tree height decreased with increasing rates of water table decline. These results are in agreement with ours.

Analyzing the relations between the ADMinc and PAWC, it was found that out of the three investigated tree species, the strongest correlation $\left(\mathrm{rsp}_{\mathrm{sp}}=0.54\right)$ was found between the growth of Black locust and the PAWC of the soil (Figure 1). This relationship was stronger, than that of for all forest types (Figure 1). There were just a few data available for the oak forests, thus the analysis can't be done. Growth of the poplar is not depending on the PAWC of the soil, there is no significant correlation between them. It strongly $\left(\mathrm{r}_{\mathrm{Sp}}=0.85, \mathrm{p}=0.004, \mathrm{~N}=9\right)$ depend on the GWU, instead. Vigor of growth of different tree species is reflected in the slope of the linear regression (Figure 1: 9.92 - poplar $>5.82-$ black locust, oak cannot be evaluated).

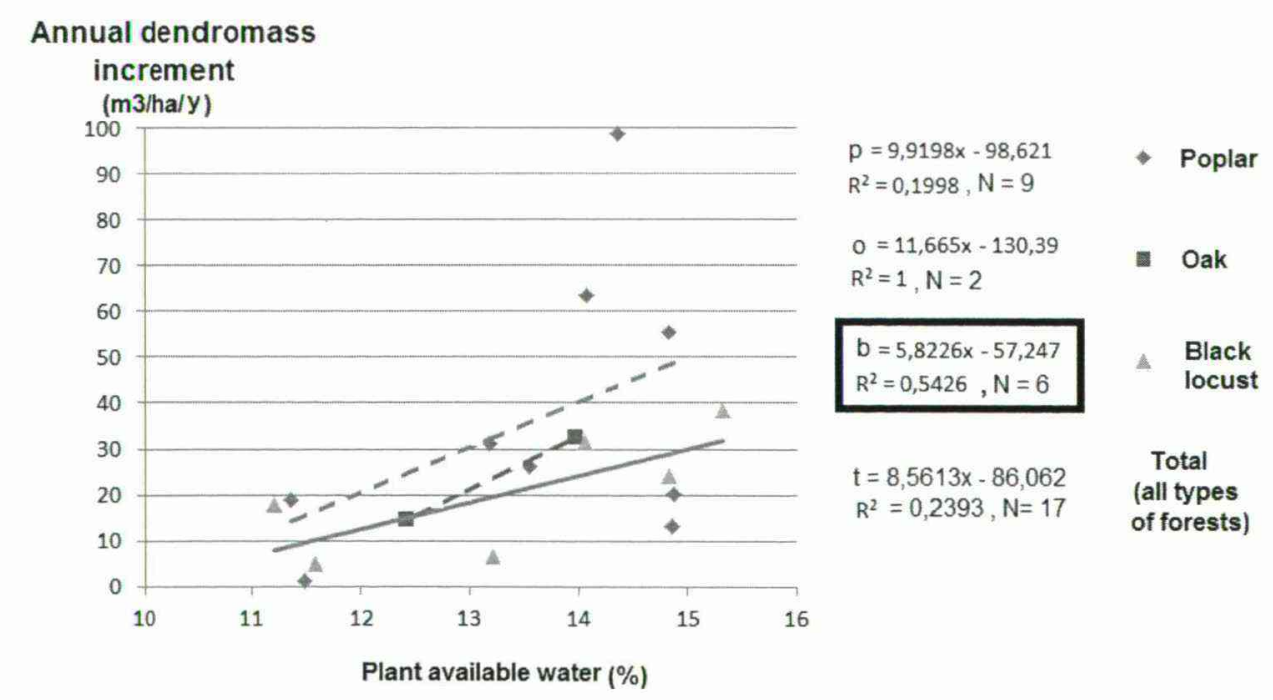

Figure 1. The effect of PAWC (\%) on $\operatorname{ADM}_{\text {inc }}\left(\mathrm{m}^{3} / \mathrm{ha} / \mathrm{year}\right)$

(Dashed lines represent weak coefficient of determination or insufficient data number.) 
TÜFEKCIOGLU (2005) also did not find significant correlation between PAWC and poplar growth in Turkey. In contrast, Bergante et al. (2010) carried out a study on young (irrigated) poplar plantations (in the first 2 years of short rotation coppices) in Po valley, and found that water availability was the main variable driving biomass production. In this case, the difference between the results can be commented by the fact, that the roots of young poplar trees are not developed enough to reach groundwater, so it is forced to uptake moisture from the unsaturated soil (PAWC).

Among anions, $\mathrm{ADM}$ inc depends on the concentration of $\mathrm{HCO}_{3}{ }^{-}$in the groundwater $\left(\mathrm{gwHCO}_{3}\right)$ according to the following equation:

(applying one-way ANOVA).

$$
\mathrm{ADM}_{\mathrm{inc}}=64.129-2.721 * \mathrm{gwHCO}_{3}
$$

$\mathrm{ADM}_{\text {inc }}$ is inhibited by the high level $(>15 \mathrm{meq} / \mathrm{l})$ of $\mathrm{HCO}_{3}{ }^{-}$in groundwater $\left(\mathrm{rsp}_{\mathrm{sp}}=-0.48\right.$, $\mathrm{p}=0.098, \mathrm{~N}=13$ ). In case of cations, there is no relationship with ADMinc.

Relationship between the thickness of the humus layer and $A D M$ inc is significant $(p=0.055)$ but not strong $\left(\mathrm{r}_{\mathrm{Sp}}=0.223\right)$. If the soil has deep humus layer, $\mathrm{ADM}_{\text {inc }}$ increases exponentially (Figure $2 A$ ). Significant $(\mathrm{p}=0.055)$, but not too strong $\left(\mathrm{rsp}_{\mathrm{p}}=0.473\right)$ correlation can be discovered between the genetic type of soil and humus layer thickness, as well (Figure 2B). Among the investigated soil types only MSC, MCS and HSS can be evaluated due to the low number of samples from the other soil types (abbreviations explained in Figure 2 legend). MSC has the deepest humus layer (Figure 2B), and parallel helps to reach the highest $\mathrm{ADM}_{\text {inc. }}$ HSS has the shallowest humus layer resulting in the smallest increase in ADMinc (Figure $2 B$ and C). BIDLó (2014) stated that tree growth is defined mostly by the humus layer and physical characteristic of the soil (Zala County, Hungary). Large differences were found in the growth of beech stands on soils with different thickness of humus layers, but this relationship was linear.
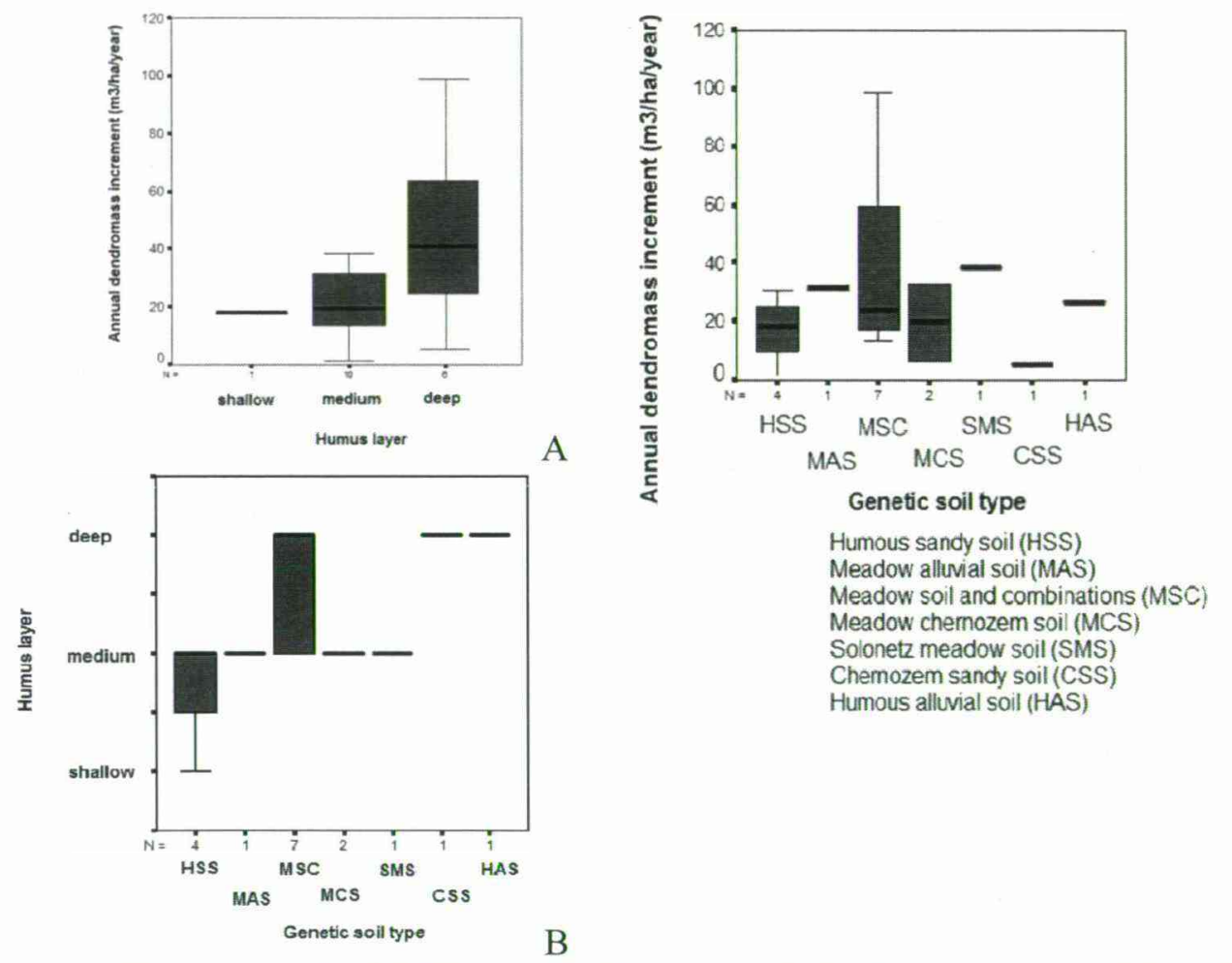

Figure 2. Distribution of the $\mathrm{ADM}_{\mathrm{inc}}$ and thickness of the humus layer (A), $A D M_{\text {inc }}$ and genetic soil type (B), thickness of the humus layer and genetic soil type (C) represented by boxplot 
There is no direct correlation between soil $\mathrm{pH}$ and $\mathrm{ADM}_{\text {inc }}$, but $\mathrm{gwHCO} 3$ is connected to both, unsaturated $\left(\mathrm{rsp}_{\mathrm{p}}=0.652, \mathrm{p}=0.016, \mathrm{~N}=13\right)$ and saturated soil $\mathrm{pH}\left(\mathrm{rSp}_{\mathrm{p}}=0.725, \mathrm{p}=0.005\right.$, $\mathrm{N}=13$ ) significantly.

Electrical conductivity (EC) of soil is generally understood to be the total water-soluble salt content (TSC) of the soil that involves both useful and harmful salts of nutrients relevant to the plant nutrition - in an electrically conductive mixture. The soils that are well supplied with nutrients have higher TSC, than the weakly supplied ones. Besides, EC value is influenced by moisture content and texture of the soil.

The statistical analysis showed that a significant $(\mathrm{p}=0.021)$, moderately strong, positive $\left(\mathrm{rsp}_{\mathrm{sp}}=0.682, \mathrm{~N}=11\right)$ relationship have disclosed between the extent of EC maximum in

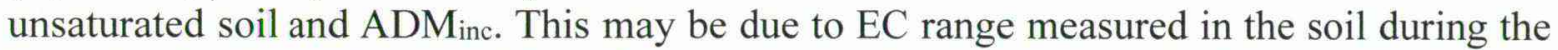
investigation is moderate: $0.17-2.23 \mathrm{mS} / \mathrm{cm}$, which equals to $\sim 136-1784 \mathrm{mg} / \mathrm{l} \mathrm{TSC}$. This range is lower than the tolerance limit of the studied trees and coincides with the EC values of soils with beneficial nutrient supply for plants $(1-2 \mathrm{mS} / \mathrm{cm})$. Thus, available nutrient supply of these soils known to be good and promotes optimal growth.

EVERS ET AL. (1997) investigated poplar sooths growth under $\mathrm{NaCl}$ stress $(300 \mathrm{mmol} / \mathrm{l})$ and stated that after 28 days, both the shoot and root growth decreased compared to control. According to TÜFEKCIOGLU (2005), $\mathrm{Mg}^{2+}$ content of the soil showed a significantly negative correlation with the growth of poplar. Thus both $\mathrm{Na}$ - and $\mathrm{Mg}$-salts in soil expose inhibitory effect on tree growth if being in high quantities. SHANNON ET AL (1999) stated that waste water, having high TSC - used as irrigation water in sandy soil environment (Riverside, CA, USA) - reduced growth of poplars. But all of these studies were carried out under higher salt concentrations, than our investigation.

There is no relationship between $\mathrm{CaCO}_{3}$ and $\mathrm{ADM}_{\text {inc. }}$. DouInEAU (1942) promoted phrase "percent active lime content" that means the $\mathrm{CaCO}_{3}$ content in the clay+fine silt fraction of the soil, indirectly responsible for plant growth reductions and physiological disorders. CARTER (1981) stated that in poplar plantations on Chernozemic soils, active $\mathrm{CaCO}_{3}$ exceeding $7-9 \%$ causes stunted growth of the plantation. In our case, mean $\mathrm{CaCO}_{3}$ of the soils is $8.2 \%$ in the whole profile, so only a small part of this value can be found in the fine fraction, which has no influence on tree growth.

Both the depth of $\mathrm{EC}$ and $\mathrm{CaCO}_{3}$ maximum has no correlation with $\mathrm{ADM}_{\text {inc, }}$ neither in their absolute value, nor in relation to the depth of the root zone.

Tree roots are located in its largest number and weight in the unsaturated zone of the soil (2,5-5,5 $\mathrm{m}$ according to PHILliPS ET AL., 2014). There is significant $(\mathrm{p}=0.017)$ and moderate to strong positive relationship ( $\mathrm{rsp}_{\mathrm{sp}}=0.651, \mathrm{~N}=17$ ) between the texture of unsaturated zone in the soil (hy1) and ADMinc. It means that the higher fine particles of soils (loam and clay) the higher growth of trees. In line with our results, DECKMYN et al. (2004) stated in short rotation coppices, that poplar growth was strongly reduced (from $12,4 \mathrm{t} / \mathrm{ha} /$ year to $6 \mathrm{t} / \mathrm{ha} /$ year) on sandy soils, due to severe drought stress can occur. In contrast, TÜFEKCIOGLU (2005) stated that sand content of the soil had a positive correlation with the growth of poplar due to improved soil aeration, and clay content showed a significantly negative correlation with that, due to high clay content may have high waterholding capacities but inadequate aeration. His experiments were performed on clayey soils with high fine soil particle content (mean clay+silt: $78.6 \%$ ), whereas on our sample areas, soil texture was mainly sandy loam with the mean of 1.92 hy1 $30 \%$ fine soil particles, which explains the difference between the results. BERGANTE ET AL. (2010) draws attention to the fact that soil texture and organic matter content may interact with plant growth by influencing soil structure and hydrological characteristics.

Our database includes few elements to clearly evince correlations between mean rainfall in the vegetation period and ADMinc, or between aridity index (DÖVÉNYI, 2010) and ADMinc. 
For proving the context of climatic parameters and ADMinc, further investigation is needed on other sampling plots. In the above mentioned study of BERGANTE ET AL. (2010), no correlation was found between production and annual mean temperature in young poplar plantations. According to DECKMYN ET AL. (2004), drought reduces poplar growth on all soils types during summer.

\section{CONCLUSIONS}

The results indicate that soil conditions have a strong influence on the growth of forests within the Great Hungarian Plain. Result of the study is shown as a correlation profile (Figure 3), which summarizes soil parameters affecting the growth of forests.

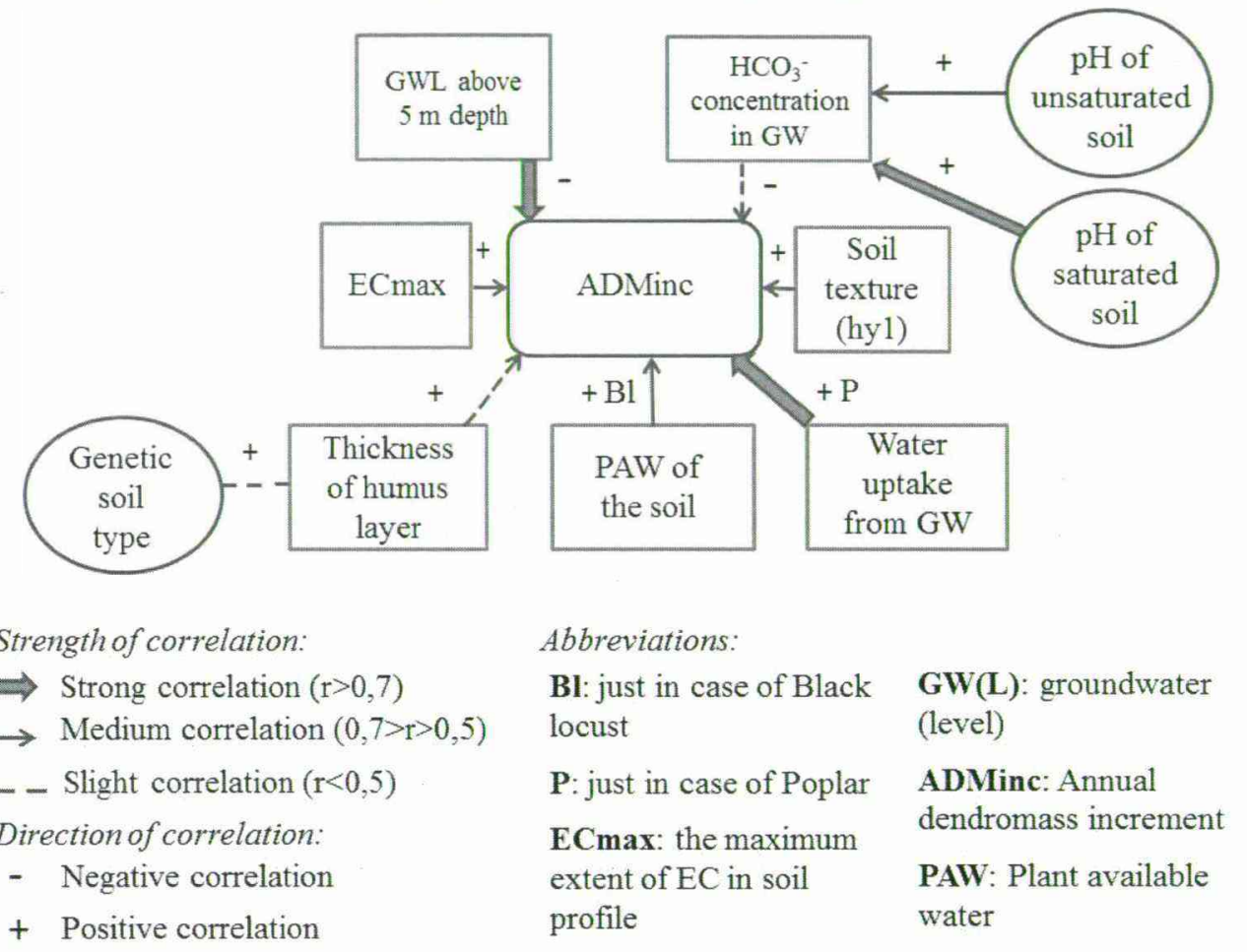

Figure 3. Correlation profile of the $\mathrm{ADM}_{\text {inc }}$ influencing parameters. Exclusively significant correlations are presented. r: Spearman type correlation coefficient

Knowledge of the relationship between soil features and tree growth is necessary for further cost-benefit analysis and land evaluation. Results can help us to understand the limits of each soil parameters, that would be fulfill to have a productive plantation in the Great Hungarian Plain. In order to get a similar correlation model for the relation of climatic parameters and tree growth, more sample sites have to be studied for a longer period.

\section{ACKNOWLEDGEMENTS}

This research was supported by OTKA NN 79835 project and Postdoctoral Research Program of HAS No. PD-029/2015. 


\section{REFERENCES}

Bergante, S., Facciotto, G., Minotta, G. (2010): Identification of the main site factors and management intensity affecting the establishment of Short-Rotation-Coppices (SRC) in Northern Italy through Stepwise regression analysis, Cent. Eur. J. Biol. 5(4): 522-530. BIDLÓ A. (2014): Effect of changes in production site on yield of trees (in Hungarian), In: Bidló A, KirÁly A, MÁTYÁs Cs (eds.) AgroClimate: Impact assessment of the projected climate change and adaptation options for forestry and agricultural sector. Sopron: Nyugatmagyarországi Egyetem Kiadó, 2014. pp. 48-53.

CARTER, M. R. (1981): Association of total $\mathrm{CaCO}_{3}$ and active $\mathrm{CaCO}_{3}$ with growth of five tree species on Chernozem soils, Canadian Journal of Soil Science 61: 173-175

Deckmyn, G., Laureysens, I., Garcia, J., Muys, B., Ceulemans, R. (2004): Poplar growth and yield in short rotation coppice: model simulations using the process model SECRETS, Biomass and Bioenergy 26(3): 221-227.

Di Bene, C., Pellegrino, E., Tozzini, C., Bonari, E. (2011): Changes in soil quality following poplar short-rotation forestry under different cutting cycles, Italian Journal of Agronomy 6/e6: 28-35.

Douineau, G. (1942): Dosage rapide ducalcaire actif des sols. Nouvelles données sur la répétition et la nature des fractions calcaires. Ann. Agron. 2: 441-450.

DÖVÉNYI Z. (szerk.) (2010): Magyarország kistájainak katasztere, Bp., MTA FKI, 876 p.

Evers, D., Schmit, C., Mailliet, Y., Hausman, F. (1997): Growth Characteristics and Biochemical Changes of Poplar Shoots in vitro under Sodium Chloride Stress, Journal of Plant Physiology 151: 748-753.

Gries, D, Zeng, F, Foetzki, A, Arndt, SK, Bruelheide, H., Thomas, F. M., Zhang, X., Runge, M. (2003): Growth and water relations of Tamarix ramosissima and Populus euphratica on Taklamakan desert dunes in relation to depth to a permanent water table, Plant, cell \& Environment 26(5): 725-736.

GUO Y.J., HAN J.G. (2008): Soil biochemical properties and arbuscular mycorrhizal fungi as affected by afforestation of rangelands in northern China. J. Arid Environ. 72: 16901967.

Kuster, T. M., Arend, M., Bleuler, P., Günthardt-Goerg, M. S., Schulin, R. (2013): Water regime and growth of young oak stands subjected to air-warming and drought on two different forest soils in a model ecosystem experiment, Plant Biology 15(s1): 138-147.

KUTI L. (1981): Az Alföld földtani atlasza. Kecskemét. Budapest: MÁFI

KUTI L. (1982): Az Alföld földtani atlasza. Debrecen-Nyírábrány. Manuscript.

KuTi L. (1984): Az Alföld földtani atlasza. Mátészalka. Manuscript.

KuTI L. (1986): Az Alföld földtani atlasza. Dabas. Budapest: MÁFI

Nosetto, M. D., Jobbágy, E. G., Tóth T., Di Bella, C. M. (2007): The effects of tree establishment on water and salt dynamics in naturally salt-affected grasslands, Oecologia 152: 695-705.

MAHONEY, J. M., RoOD, S. B. (1992): Response of a hybrid poplar to water table decline in different substrates, Forest Ecology and Management 54(1-4): 141-156.

Michelot, A., BRÉDA, N., DAMESIN, C., Dufrêne, E. (2012): Differing growth responses to climatic variations and soil water deficits of Fagus sylvatica, Quercus petraea and Pinus sylvestris in a temperate forest, Forest Ecology and Management 265: 161-171.

Phillips, C. J., MARden, M., Suzanne, L. M. (2014): Observations of root growth of young poplar and willow planting types, New Zealand Journal of Forestry Science 44(15): $2-12$. 